\title{
Can Individual Investors Capture The Value Premium?
}

Patrick J. Larkin, Fayetteville State University, USA

\begin{abstract}
I test the performance of several simple one and two-factor mechanical GARP and value investment strategies against a value-weighted market portfolio for the period 1998-2006, focusing on the suitability of the strategies for individual investors. All of the GARP and value strategies produce substantially higher average returns than the market portfolio over the 97 rolling one-year holding periods included in the study. The strategies have a higher standard deviation of returns across the 97 start months, but are less likely than the market portfolio to experience negative returns over any three or five-year time period. Overall, the best performing strategies are EBIT to enterprise value and return on capital, EBIT to enterprise value alone, and earnings yield (the inverse of the P/E ratio). Adding a profitability factor to form a GARP strategy from a simple one-factor value strategy does not appear boost performance, though it does reduce risk in the EBIT to enterprise value and return on capital strategy. My results indicate that individual investors who are able to tolerate occasional underperformance should consider using a GARP or value strategy in at least a portion of the portion of their portfolio that is allocated to U.S. equities.
\end{abstract}

Keywords: value premium, individual investors, value investing

\section{INTRODUCTION}

$\mathrm{t}$ is well known that value stocks have historically earned higher returns than growth stocks. A lively debate still exists over the question of whether this value premium exists because value stocks are riskier or because the market is inefficient. A good brief summary of this debate is available in Davis (2001). I do not take a position on this debate here. Instead, I begin with the assumption that some individual investors wish to concentrate their equity exposure in value stocks, either because they believe that value stocks offer superior riskadjusted returns or because they believe themselves well positioned to bare the systematic risks associated with owning value stocks. I then address the practical question of how individual investors can best gain exposure to value stocks. In addition to traditional value strategies such as investing in stocks with low ratios of book-to-market value (B/M), I focus on growth at a reasonable price (GARP) strategies, which I view to be a subset of value investing. Part of my motivation comes from the results of Greenblatt's 2006 book "The Little Book That Beats the Market." Greenblatt reports that a simple stock selection rule based on return on capital (ROC) and the EBIT to Enterprise Value ratio (referred to as "the magic formula") produces annualized returns of over $30 \%$ per year on a portfolio of approximately thirty stocks from 1987-2004. In a study posted on his company's website, Haugen (2008) finds that several alternative pairings of valuation and profitability factors perform slightly better than a proxy for the Greenblatt factors for large cap stocks from 1996 through 2005, but that none of the pairings earn statistically significant excess returns over that time period when benchmarked against the S\&P 500. Haugen's objective is not to replicate the Greenblatt study, but to refute Greenblatt's claim that the magic formula outperforms Haugen's sophisticated multi-factor model for large stocks. Haugen concludes that Greenblatt's magic formula is merely one of numerous variants of the GARP strategy that is likely to produce superior returns. In this study I compare and analyze the performance of the magic formula and seven other one and two-factor GARP and value based strategies. Unlike Haugen, my emphasis is on the suitability of these mechanical strategies for individual investors. 
The definition of GARP is not as well established in the academic literature as is the definition of value. I define a value stock as a stock with a low share price relative to some plausible proxy for the intrinsic value of the firm's equity, such as book value of equity, earnings, or cash flow. I define a GARP stock as a value stock that also has high profitability or cash flow relative to some measure of invested capital, equity, or assets. The " $G$ " in my definition of GARP thus refers more to profitability than to growth, though profitability is a necessary condition for profit growth. My definition of GARP is consistent with both Greenblatt (2006) and Haugen (2008). There is support for GARP in the academic literature. Haugen and Baker (1996), Cohen, Gompers, and Vuolteenaho (2002), and Fama and French (2007) all report a positive relationship between past profitability and future returns for profitable firms. The literature on the value premium is too vast to summarize here, but in addition to Davis' brief summary mentioned above, Haugen (1995) presents a useful treatment of much of the earlier work. In addition to Greenblatt's magic formula, I test four other GARP strategies. I test return on assets (ROA) and the earnings yield ( $\mathrm{E} / \mathrm{P}$ - the inverse of the $\mathrm{P} / \mathrm{E}$ ratio) because it is Greenblatt's recommended substitute formula for investors who are using stock screeners that do not include ROC or EBIT / Enterprise Value (EBIT/EV). I also test return on equity (ROE) and E/P because these variables will not be influenced by debt levels and interest expense in the same way that the prior two strategies will be. I also test one-factor strategies using EBIT/EV and E/P alone.

The other three strategies that I test are B/M combined with market capitalization (Size) B/M alone, and Size alone. B/M and Size are the variables that Fama and French $(1992,1993)$ find to have the most explanatory power for the cross-section of stock returns. $\mathrm{B} / \mathrm{M}$ is a value factor that does not have a profitability factor imbedded in it, so it is not a GARP factor according to my definition. I are interested in whether GARP strategies provide any advantage in terms of either risk or returns over these well-documented sources of high returns. My Size alone strategy results in selecting 30 stocks that are just above the $\$ 50$ million (in December 2003 dollars) market capitalization cutoff for my study. Most stock selection strategies that use a relatively low market capitalization cutoff will pick mostly stocks that would be classified as microcaps by investment managers. This is true simply because the majority of stocks trading in the U.S. are microcaps. For example, Fama and French (2007) report that on average for the period 1962 to $200560 \%$ of the stocks in their sample are microcaps, though microcaps only constitute about $3 \%$ of total market capitalization on average over the sample period. This is not a problem provided that the stocks have sufficient liquidity so that individual investors can purchase them without affecting prices. However, there is clearly nothing special about GARP strategies if they are unable to outperform a simple sizebased strategy.

I also compare the performance of the GARP strategies to the performance of a broad value weighted average of U.S. stocks. While such a broad average might not be considered suitable as a benchmark for an active value manager, it does serve as a good basis for comparison for the typical individual investor. The diversification advantages of value-weighted indexing through a fund such as Vanguard's Total Stock Market Fund are well known. Recent studies have found that the number of stocks needed to obtain adequate diversification has increased, and that under diversification is costly for investors. For instance, Statman (2004) estimates that the optimal level of diversification for a randomly selected portfolio exceeds 300 stocks. Following Statman's assumptions, a randomly selected portfolio of 30 stocks would be expected to under perform the Vanguard Total Stock Market Fund by approximately $0.6 \%$ per year, adjusting for volatility. Individual investors, particularly those who ascribe to the view that value and GARP strategies contain greater than average systematic risk, will want to compare the returns to the strategies with the returns available from highly diversified, low cost, and relatively tax-efficient value-weighted index funds.

Next, in the data and methodology section, I outline my procedure for forming portfolios based on the strategies tested and describe the features and limitations of my data. I then present and discuss the results of my tests. Next, I briefly discuss the option of investing in value mutual funds. Finally, I make a few concluding remarks.

\section{DATA AND METHODOLOGY}

I follow Greenblatt's procedure in selecting stocks based on my eight strategies. For each strategy, I rank each stock on each factor in ascending order for each of my 97 portfolio formation months from December of 1997 through December of 2005. For two-factor strategies, I add the ranks for each factor and then rank the stocks in the sample in ascending order from best to worst. For example, in the magic formula strategy, if a firm has the second 
highest ROC in a given formation month and the twelfth highest EBIT/EV, it would receive a combined score of 14 . If that were the lowest combined score for that formation month, the firm would receive a rank of 1 for the magic formula strategy for that formation month. The only exception to this ranking method is with the Size variable, where smaller size corresponds to a higher rank. Next, I depart a bit from Greenblatt's method and select the top 30 stocks for each formation month for each strategy and compute the equally weighted one-year forward rate of return for the 30-stock portfolios. Greenblatt advocates starting out largely in cash and adding a few stocks per month, gradually, working one's way up to an approximately 30 -stock portfolio over a period of several months to a year. One result of this is that portfolios for different start months are guaranteed to overlap a great deal. My method of forming a new portfolio in each starting month allows us to potentially obtain more information from measuring the mean and standard deviation of the rolling annual portfolio returns over my 97 formation months (see my Table 2). These tests are not as statistically reliable as tests using large samples of non-overlapping time periods, but I (like Greenblatt) am interested in the performance of the strategies over one-year holding periods and I do not have access to over 30 years of data. If the magic formula and other strategies tested are clearly superior to indexing then their out performance should be robust to this minor change in implementation. In addition to the standard deviation of one-year returns across the 97 formation months, the measures of risk that I examine are the probabilities of a strategy losing money or under performing the market over any given three or five-year period.

One advantage of Greenblatt's study is that it utilizes the relatively new Compustat Point in Time database. The Point in Time database contains "as reported" data. This allows for more accurate back testing of investment strategies because it avoids "look ahead bias." For example, while it is possible that an actual investor using the magic formula or a similar strategy would have selected a stock like WorldCom or Enron for inclusion in their portfolio in the year that these companies filed for bankruptcy, a researcher using the standard Compustat Research Insight database would not select these stocks for inclusion in a back test. Unfortunately, I did not have access to the Point in Time database for this study, but instead rely on the standard Compustat Research Insight database, which is corrected for restatements of financial statements. If most restatements are downward, then back tests using the standard Compustat Research Insight database could potentially over estimate the returns to the strategies tested here. This is a problem that is shared by other studies. To attempt to ensure that I are using the most recent data available to investors in most cases, I use quarterly accounting data from the standard Compustat Research Insight database. I assume that investors do not have access to the quarterly report or annual report for the most recently ended quarter when they form portfolios, but that they do have access to the report immediately preceding the report for the most recently ended quarter. For example, for portfolios formed at the end of February for a company with a calendar fiscal year, I assume that the most recent report available comes from the September quarterly report. This assumption is conservative relative to the time frame allotted by the SEC for public companies to file quarterly and annual reports, and leaves time for the data to be aggregated into databases and screeners that may be used by individual investors. Still, there are cases where companies file late, and it is possible that some of those companies could have ended up in my portfolios. However, if we assume that most companies that file late are experiencing some type of distress then it is unlikely that they will end up in any of my GARP portfolios.

My investment universe includes all U.S. stocks in the Compustat Research Insight database with a market capitalization of at least $\$ 50$ million in December 2003 dollars, with the exceptions of financials, utility stocks, and ADRs. I follow Greenblatt in excluding financials because Compustat does not contain some of the data necessary to compute the factors in some of the strategies for financials. Greenblatt repeats his tests of the magic formula with three market capitalization based universes, and reports that the smallest stock in his smallest universe had a market capitalization of about $\$ 50$ million. Greenblatt, an experienced hedge-fund manager, implies (see pgs. 59-60 of Greenblatt) that most individuals could purchase a stock of this size in a meaningful quantity without affecting the price, at least as of December, 2003, the final portfolio formation month for Greenblatt's study. I adjust all market capitalizations to December 2003 dollars to ensure that stocks that appear in my samples after December of 2003 are large enough to meet Greenblatt's liquidity standard. I also require that a stock has the data necessary to compute the returns to all eight of the strategies that I test to be included in the sample for a given portfolio formation month. If a stock has data for EBIT/EV in a given month but not for ROC, for example, it is not ranked for possible inclusion in the EBIT/EV strategy portfolio or any other strategy portfolio for that formation month. This allows for a more reliable comparison of the performance of the various strategies in a given formation month. Since only 48 quarters of quarterly data are available from Compustat Research Insight and I have to obtain data from trailing quarters to compute variables such as ROC and data from forward months to compute returns, I are limited to 97 portfolio 
formation months, beginning in December of 1997 and ending in December of 2005. I assume that portfolios are formed at the close of the final trading day of each month. The selection criteria described above result in there being as few as 2,354 and as many as 3,631 stocks included in my sample, depending on the formation month.

Yearly returns to the stocks in the strategies are calculated by compounding and annualizing monthly returns from Compustat. I require that a stock have a return listed in Compustat in month $t+1$, where month $t$ is the portfolio formation month. For example, for portfolios formed at the end of December, I require a monthly return for January. I do not require any returns after month $t+1$, as I expect returns data for some firms to disappear due to takeovers or bankruptcy filings. If returns disappear after month $\mathrm{t}+1$, I simply compound as many months of returns as are available and annualize them. Another option, which would be appropriate for takeovers, is to assume that investors earn a risk-free rate of return over the remaining months of the year. However, since I can't always be sure why returns break off, I choose the more conservative option of simply computing the annual return based on the monthly returns that are present.

All accounting variables and market values are calculated from quarterly data available on Compustat. EBIT/EV is earnings before interest and taxes (EBITQ in Compustat) divided by enterprise value. Enterprise value is calculated as the market value of common equity (MKVALM) plus the book value of preferred stock (PSTKQ) plus the book value of long-term debt (DLTTQ) plus the book value of short-term debt (DLCQ) minus cash and equivalents (CHEQ). The Greenblatt study uses "net interest bearing debt" in the enterprise value calculation. I interpret this to mean interest-bearing debt minus cash. Since my EBIT measure does not include interest income from cash holdings, it is correct to exclude cash from the enterprise value calculation. ROC is the return on capital, calculated as EBIT divided by net tangible assets. Net tangible assets are calculated as net fixed assets (PPENTQ) plus total current assets (ACTQ) minus cash (CHEQ) minus total current liabilities (LCTQ) plus short-term debt (DLCQ). E/P is calculated as earnings divided by the market value of common equity (MKVALM). Earnings are defined as net income (NIQ) minus preferred dividends (DVPQ). ROE is the return on equity, calculated as earnings divided by the book value of common equity. ROA is the return on assets, calculated as earnings divided by the book value of assets (ATQ). B/M is the book-to-market ratio, calculated as the book value of common equity divided by the market value of common equity. Size is calculated as the market value of common equity. I calculate earnings and EBIT using the most recent four quarters of data likely to be available to investors as of the portfolio formation month. Balance sheet data used in calculating ROC, ROE, and ROA is from the quarterly balance sheet immediately preceding the oldest quarterly income statement used to calculate earnings and EBIT. Balance sheet data used in calculating EV and $\mathrm{B} / \mathrm{M}$ is from the most recent quarterly balance sheet available to investors as of the portfolio formation month. The market portfolio is the value-weighted annual return on all NYSE, AMEX, and NASDAQ stocks, calculated from monthly data available on Professor Kenneth French's website at Dartmouth University. The annual returns on this portfolio should closely track the returns on the Vanguard Total Stock Market Index fund.

\section{RESULTS AND DISCUSSION}

In table 1 I present raw returns for each strategy for each year of the sample period and annualized raw returns for each strategy for the entire nine-year sample period. All portfolios are initially formed at the end of December of 1997 and are reformed at the end of December every year through December of 2005. All strategies tested beat the market by a substantial margin over the full sample period. The strategy that really stands out is the $\mathrm{B} / \mathrm{M}$ and Size strategy, with an annualized return of $32.02 \%$ over the sample period. Most of the strategies hold up well in the down market of $2000-2002$, though the B/M and B/M and Size strategies experience outstanding performance in 2001 sandwiched between losing years in 2000 and 2002. Regarding the magic formula, my results are somewhat different from the annual results presented on page 56 of Greenblatt for the years in which the two studies overlap, but this should not be surprising given the difference in my portfolio formation procedure. The years 2005 and 2006 are out of sample years for the Greenblatt study. While my results do not account for the bid-ask spread due to data limitations, the sheer magnitude of the outperformance of the strategies tested mitigates this weakness.

In Table 2 I present statistics for the 97 rolling one-year holding periods for each strategy. To make sure that the information being presented in the table is clear, the first of the 97 periods begins at the end of December of 
1997 and goes through the end of December of 1998; the second period begins at the end of January of 1998 and goes through the end of January of 1999, and the last period begins at the end of December of 2005 and goes through the end of December of 2006. The first two columns of Table 2 present the mean and standard deviation for each strategy over the 97 formation months. Note that the B/M and Size strategy still has the highest average yearly return, but also has a higher standard deviation of annual returns than any strategy except B/M alone. All of the strategies have substantially higher average raw returns than the value-weighted market portfolio, but all also have higher standard deviations of returns.

The next three columns of Table 2 present the mean and standard deviation of the difference in each strategy's rolling yearly returns minus the rolling yearly returns on the market, and the t-statistic for the difference. For each strategy except for $\mathrm{B} / \mathrm{M}$ alone, the t-statistic indicates that the difference between the annual return on the strategy and the market portfolio is significantly greater than zero at the $1 \%$ significance level. $\mathrm{B} / \mathrm{M}$ alone is significant at the 5\% significance level. In the next four columns, I count the number of months that each strategy lost money or under performed the market over three and five-year time horizons. Greenblatt argues that it can take the magic formula between three and five years to work, and that most investors are unable to tolerate long stretches of underperformance. Note that the holding period is still one year and that there are only 73 rolling three-year periods and 49 rolling five-year periods available. The table shows that the magic formula really stands out on this measure of risk, exhibiting no three or five year periods of negative returns and only seven three year and two five year periods of underperformance relative to the market. The next best strategy on this measure is EBIT/EV alone, exhibiting one three-year and no five-year periods of negative returns and thirteen three-year and five-year periods of underperformance. All of the other strategies under perform the market over at least 20 of the 73 rolling threeyear periods in the sample. Finally, note that the value-weighted market portfolio delivers negative returns with far more frequency than any of the GARP or value strategies do.

The final three columns of Table 2 present the mean, standard deviation, and t-statistic for the difference between the annual returns on the three GARP strategies and the value strategies that are formed by removing the profitability factor from each GARP strategy. The average returns on the magic formula and EBIT/EV alone are almost identical and not statistically significant. However, the E/P value strategy significantly outperforms the two alternative GARP strategies, E/P and ROE and E/P and ROA. Note that the addition of the profitability factors to the E/P strategy also does not materially reduce the standard deviation of returns and results in more periods of losses and underperformance.

While Table 2 provides a fairly good picture of the returns and risks of the strategies over my sample period, it is also interesting to know whether the factors selected for the strategy have a consistent relationship with returns over the full sample of stocks. While I will not attempt to answer this question in full, in Table 3 I do present the annualized returns from 1998 through 2006 for each decile of each strategy. For each strategy, decile 1 contains stocks ranked in the top $10 \%$ according to my ranking criteria, and decile 10 contains the stocks ranked in the bottom $10 \%$. For seven of the eight strategies, decile 1 has the highest compounded equally weighted return while in six of the eight strategies decile 10 has the lowest return. The biggest surprise is Table 3 is the $16.65 \%$ return of decile 10 of the E/P strategy, which is second only to decile one's $18.17 \%$ return for that strategy. This result could be due to the momentum anomaly documented by Jegadeesh and Titman (1993). However, a momentum-based explanation would have to account for the fact that the annualized return is only $3.02 \%$ in decile 10 of the B/M only strategy. Finally, while returns largely conform to the expectations of my strategies in the top and bottom deciles, no strategy comes close to exhibiting monotonicity in annualized returns across all deciles.

Which mechanical strategy is best for investors who wish to construct their own portfolios? There is an element of subjectivity to judging the performance of my GARP and value strategies relative to each other. The magic formula (EBIT/EV and ROC), EBIT/EV, and E/P all have similar and outstanding average returns and relatively low standard deviations of returns over the 97 rolling one-year periods in the study. B/M and Size had the highest average return at $26.19 \%$, but also much higher volatility than the three strategies just mentioned. The magic formula really stands out when I take into account the number of losing and under performing three and five-year periods. The magic formula under performed the market in only seven of the 73 rolling three-year periods and two of the 49 rolling five-year periods, and was never in the red for any three or five-year period. EBIT/EV and E/P also performed reasonably well on these measures. 
If the profitability factors in the two-factor GARP strategies bring anything to the table, it is a reduction in volatility, but even there the evidence is mixed. The E/P strategy alone, perhaps the best known and most widely used value strategy (when thought of as its inverse, the $\mathrm{P} / \mathrm{E}$ ratio), earns significantly higher returns than both E/P and ROE and E/P and ROA, has a similar standard deviation, and is less likely to lose money or under perform over three and five-year time horizons. On the other hand, the magic formula is almost neck and neck with EBIT/EV in average return and standard deviation, but is less likely to under perform the market. B/M, a value strategy but not a GARP strategy, has a relatively high standard deviation of annual returns and is prone to underperformance relative to my value-weighted market benchmark.

\section{VALUE FUNDS}

Another option for investors who wish to gain exposure to value stocks is to purchase mutual funds. GARP is not an established category for mutual funds, but investors who are looking to maximize expected returns over a reasonably long time horizon might look to small capitalization value funds. I investigate the returns on small-cap value funds over the period covered in my study by searching Morningstar's fund screener for small-cap value funds that existed at the beginning of 1998. The average annualized return from 1998-2006 before fees for the funds that existed throughout the entire sample period was $10.44 \%$, with a standard deviation of $2.18 \%$ across the 91 funds. Since all 91 of these funds also existed at the time that I accessed the screener in February of 2008, it seems likely that some funds that existed in 1998 but were subsequently closed are excluded from the screener. This survival bias doesn't indicate any weakness in Morningstar data, as the function of a screener is to identify funds that exist at the present time that its clients can invest in.

While the returns earned by these small-cap value funds as a group are not impressive relative to the strategies presented in this study, it should be noted that the DFA U.S. Small Cap Value Fund from Dimensional Fund Advisors, the only fund that to my knowledge explicitly seeks to provide investors with exposure to the size and book-to-market factors identified by Fama and French $(1992,1993)$ provided a more impressive annualized return of 14.30\% before fees over the 1998-2006 period, according to Morningstar. The fund has an expense ratio of $0.53 \%$ and strives for tax efficiency. Brokerage expenses associated with executing one of the strategies examined in this study would be $\$ 600$ per year assuming a brokerage commission of $\$ 10$ per trade (thirty stocks purchased and thirty sold each year), which would be $0.6 \%$ of a $\$ 100,000$ portfolio. With $100 \%$ yearly turnover, taxes might also be a bit higher with the strategy than with the DFA U.S. Small Cap Value Fund, which strives to minimize turnover. On the downside though, in order to invest in Dimensional Funds it is necessary for investors to hire a financial planner who is eligible to deal with Dimensional or willing to undergo an arduous vetting process to become eligible. In short, while investors who want value exposure might be better off on their own than with most funds, Dimensional Funds provide a reasonable alternative for some investors.

\section{CONCLUSION}

Past studies have found that simple mechanical GARP and value strategies have beaten the market by a large margin in the past. This study, which focuses on the time period $1998-2006$, provides more evidence that such simple strategies can continue to work even after the anomalies or risk factors that drive them have been well known for some time. All of the strategies tested have significantly higher returns than the value-weighted market portfolio over the sample period. These strategies might not be available to institutional investors because they tend to select smaller stocks that cannot be bought or sold in meaningful quantities by institutions without significantly affecting prices. Some individual investors are better positioned to take advantage of the higher expected returns offered by GARP and value strategies than institutions are. These investors don't necessarily have to have a higher risk tolerance, though that depends on how risk is defined. All of the strategies tested here have a higher volatility of portfolio returns than the market, as measured by standard deviation. However, this volatility is centered on a significantly higher expected return, resulting in a lower probability of experiencing financial loss over an extended time period. What seems to be required for investors to benefit from GARP or value strategies is the ability to tolerate periodic portfolio underperformance without changing course. Perhaps this is another way of saying that investors must be well prepared to shoulder the systematic risks of these strategies in order to enjoy their high expected returns. There are no guarantees of success, but the odds seem to be stacked in favor of the patient GARP or value investor. 
Table 1: Annual Returns on GARP and Value Investment Strategies

\begin{tabular}{|c|c|c|c|c|c|c|c|c|c|c|}
\hline Strategy & 1998 & 1999 & 2000 & 2001 & 2002 & 2003 & 2004 & 2005 & 2006 & $1998-2006$ \\
\hline EBIT/EV and ROC & 0.0250 & 0.3522 & 0.1993 & 0.2000 & 0.0423 & 0.4515 & 0.1951 & 0.1531 & 0.1629 & 0.1914 \\
\hline $\mathrm{E} / \mathrm{P}$ and $\mathrm{ROE}$ & -0.1269 & 0.0637 & 0.0335 & 0.1525 & 0.1405 & 0.5741 & 0.2583 & 0.0486 & 0.2512 & 0.1410 \\
\hline $\mathrm{E} / \mathrm{P}$ and $\mathrm{ROA}$ & -0.0901 & 0.1420 & 0.0139 & 0.2193 & -0.0326 & 0.6217 & 0.2996 & 0.0794 & 0.2040 & 0.1458 \\
\hline $\mathrm{B} / \mathrm{M}$ and SIZE & 0.1467 & 0.7415 & -0.0939 & 0.5770 & -0.0546 & 1.3184 & 0.4076 & 0.1916 & 0.1614 & 0.3202 \\
\hline EBIT / EV & -0.0451 & 0.1046 & -0.0676 & 0.4392 & 0.0685 & 0.4500 & 0.1989 & 0.1090 & 0.3068 & 0.1602 \\
\hline $\mathrm{E} / \mathrm{P}$ & -0.1335 & 0.0446 & 0.2080 & 0.3424 & 0.0336 & 0.6236 & 0.3413 & 0.0965 & 0.2058 & 0.1780 \\
\hline $\mathrm{B} / \mathrm{M}$ & -0.0549 & 0.4532 & -0.3156 & 0.8261 & -0.2394 & 1.4168 & 0.1722 & 0.0373 & 0.1688 & 0.1814 \\
\hline SIZE & -0.1045 & 1.1782 & -0.0160 & 0.2836 & 0.1374 & 1.1406 & 0.1583 & -0.1773 & 0.0463 & 0.2198 \\
\hline MARKET & 0.2228 & 0.2528 & -0.1105 & -0.1127 & -0.2083 & 0.3313 & 0.1301 & 0.0732 & 0.1625 & 0.0673 \\
\hline
\end{tabular}

Table 2: Statistics for Rolling Annual Returns on GARP and Value Investment Strategies, 1998 - 2006

\begin{tabular}{|c|c|c|c|c|c|c|c|c|c|c|c|c|}
\hline Strategy & $\begin{array}{l}\text { Mean of } \\
\text { Strategy }\end{array}$ & $\begin{array}{c}\text { Standard } \\
\text { Deviation } \\
\text { of } \\
\text { Strategy }\end{array}$ & $\begin{array}{c}\text { Mean of } \\
\text { Strategy } \\
\text { Return } \\
\text { Minus } \\
\text { Market } \\
\text { Return }\end{array}$ & $\begin{array}{c}\text { Standard } \\
\text { Deviatio } \\
\text { n of } \\
\text { Strategy } \\
\text { Return } \\
\text { Minus } \\
\text { Market } \\
\text { Return }\end{array}$ & $\begin{array}{c}\text { T-Statistic } \\
\text { of } \\
\text { Strategy } \\
\text { Return } \\
\text { Minus } \\
\text { Market } \\
\text { Return }\end{array}$ & $\begin{array}{c}\begin{array}{c}\text { Number } \\
\text { of } \\
\text { Rolling }\end{array} \\
\text { 3-Year } \\
\text { Periods } \\
\text { (out of } \\
\text { 73) with } \\
\text { Negative } \\
\text { Returns }\end{array}$ & 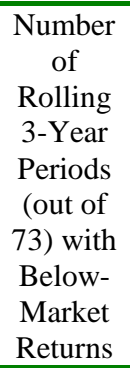 & $\begin{array}{c}\begin{array}{c}\text { Number } \\
\text { of } \\
\text { Rolling }\end{array} \\
\text { 5-Year } \\
\text { Periods } \\
\text { (out of } \\
\text { 49) with } \\
\text { Negative } \\
\text { Returns }\end{array}$ & 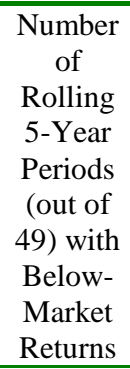 & $\begin{array}{c}\text { Mean of } \\
\text { GARP } \\
\text { Strategy } \\
\text { Return } \\
\text { Minus } \\
\text { Value } \\
\text { Strategy } \\
\text { Return }\end{array}$ & $\begin{array}{c}\text { Standard } \\
\text { Deviatio } \\
\text { n of } \\
\text { GARP } \\
\text { Strategy } \\
\text { Return } \\
\text { Minus } \\
\text { Value } \\
\text { Strategy } \\
\text { Return }\end{array}$ & $\begin{array}{c}\text { T-Statistic } \\
\text { of GARP } \\
\text { Strategy } \\
\text { Return } \\
\text { Minus } \\
\text { Value } \\
\text { Strategy } \\
\text { Return }\end{array}$ \\
\hline EBIT/EV and ROC & 0.2348 & 0.2378 & 0.1648 & 0.3064 & $5.2971 * * *$ & 0 & 7 & 0 & 2 & 0.0021 & 0.1422 & 0.1426 \\
\hline $\mathrm{E} / \mathrm{P}$ and $\mathrm{ROE}$ & 0.1773 & 0.2307 & 0.1072 & 0.3142 & $3.3621 * * *$ & 7 & 28 & 0 & 10 & -0.0519 & 0.1243 & $4.1107 * * *$ \\
\hline $\mathrm{E} / \mathrm{P}$ and $\mathrm{ROA}$ & 0.1737 & 0.2433 & 0.1037 & 0.3220 & $3.1717 * * *$ & 8 & 32 & 2 & 9 & -0.0554 & 0.1469 & $3.7165 * * *$ \\
\hline $\mathrm{B} / \mathrm{M}$ and SIZE & 0.2619 & 0.4472 & 0.1919 & 0.5361 & $3.5254 * * *$ & 9 & 27 & 2 & 6 & NA & NA & NA \\
\hline EBIT / EV & 0.2327 & 0.2214 & 0.1627 & 0.3020 & $5.3060 * * *$ & 1 & 13 & 0 & 5 & NA & NA & NA \\
\hline $\mathrm{E} / \mathrm{P}$ & 0.2291 & 0.2473 & 0.1591 & 0.3404 & $4.6034 * * *$ & 1 & 20 & 0 & 6 & NA & NA & NA \\
\hline $\mathrm{B} / \mathrm{M}$ & 0.2003 & 0.5306 & 0.1303 & 0.6105 & $2.1017 * *$ & 21 & 30 & 7 & 10 & NA & NA & NA \\
\hline SIZE & 0.2391 & 0.4270 & 0.1691 & 0.5084 & $3.2758 * * *$ & 11 & 22 & 1 & 5 & NA & NA & NA \\
\hline MARKET & 0.0700 & 0.1743 & NA & NA & NA & 28 & $\mathrm{NA}$ & 25 & NA & NA & NA & NA \\
\hline
\end{tabular}


Table 3: Decile Returns of GARP and Value Investment Strategies, 1998 - 2006

\begin{tabular}{|c|c|c|c|c|c|c|c|c|c|c|}
\hline Strategy & $\begin{array}{c}\text { Decile } 1 \\
\text { Annualized } \\
\text { Return, } \\
\text { 1998-2006 }\end{array}$ & $\begin{array}{c}\text { Decile } 2 \\
\text { Annualized } \\
\text { Return, } \\
\text { 1998-2006 }\end{array}$ & $\begin{array}{c}\text { Decile } 3 \\
\text { Annualized } \\
\text { Return, } \\
\text { 1998-2006 }\end{array}$ & $\begin{array}{c}\text { Decile } 4 \\
\text { Annualized } \\
\text { Return, } \\
\text { 1998-2006 }\end{array}$ & $\begin{array}{c}\text { Decile } 5 \\
\text { Annualized } \\
\text { Return, } \\
\text { 1998-2006 }\end{array}$ & $\begin{array}{c}\text { Decile 6 } \\
\text { Annualized } \\
\text { Return, } \\
\text { 1998-2006 }\end{array}$ & $\begin{array}{c}\text { Decile } 7 \\
\text { Annualized } \\
\text { Return, } \\
\text { 1998-2006 }\end{array}$ & $\begin{array}{c}\text { Decile } 8 \\
\text { Annualized } \\
\text { Return, } \\
\text { 1998-2006 }\end{array}$ & $\begin{array}{c}\text { Decile } 9 \\
\text { Annualized } \\
\text { Return, } \\
1998-2006\end{array}$ & $\begin{array}{c}\text { Decile } 10 \\
\text { Annualized } \\
\text { Return, } \\
\text { 1998-2006 }\end{array}$ \\
\hline EBIT/EV and ROC & 0.1772 & 0.1356 & 0.1115 & 0.1473 & 0.1195 & 0.1047 & 0.1458 & 0.1318 & 0.0895 & 0.0437 \\
\hline $\mathrm{E} / \mathrm{P}$ and $\mathrm{ROE}$ & 0.1543 & 0.1358 & 0.1277 & 0.1166 & 0.1189 & 0.1312 & 0.1327 & 0.1141 & 0.0910 & 0.0984 \\
\hline $\mathrm{E} / \mathrm{P}$ and $\mathrm{ROA}$ & 0.1500 & 0.1512 & 0.1237 & 0.1211 & 0.1182 & 0.1204 & 0.1407 & 0.1038 & 0.1130 & 0.0805 \\
\hline $\mathrm{B} / \mathrm{M}$ and SIZE & 0.2191 & 0.1851 & 0.1366 & 0.1650 & 0.1177 & 0.1032 & 0.1100 & 0.0764 & 0.0770 & 0.0689 \\
\hline EBIT / EV & 0.2019 & 0.1622 & 0.1289 & 0.1328 & 0.1181 & 0.1372 & 0.0641 & 0.0825 & 0.0724 & 0.0941 \\
\hline $\mathrm{E} / \mathrm{P}$ & 0.1817 & 0.1384 & 0.1234 & 0.1410 & 0.1169 & 0.1144 & 0.0857 & 0.0782 & 0.0681 & 0.1665 \\
\hline $\mathrm{B} / \mathrm{M}$ & 0.2033 & 0.1655 & 0.1764 & 0.1436 & 0.1225 & 0.1412 & 0.1082 & 0.0926 & 0.0658 & 0.0302 \\
\hline SIZE & 0.1918 & 0.1494 & 0.1547 & 0.1202 & 0.1374 & 0.1028 & 0.0963 & 0.1039 & 0.1206 & 0.0840 \\
\hline
\end{tabular}




\section{AUTHOR INFORMATION}

Patrick J. Larkin was born in Lake County, Florida, in 1967. He received his B.A. in economics from the University of Florida in 1989. After graduation, Patrick worked in the real estate and television production industries. Patrick received his M.A. in economics from Syracuse University in 1996 and his Ph.D. in financial economics in August of 2001 from the University of New Orleans. Patrick is currently an associate professor of finance at Fayetteville State University. He has published numerous articles in referred academic journals.

\section{REFERENCES}

1. Cohen, Randolph B., Paul A. Gompers, and Tuomo Vuolteenaho, Who underreacts to cash-flow news? Evidence from trading between individuals and institutions, Journal of Financial Economics 66, pp. 409462, 2002.

2. Davis, James L., 2001, Explaining stock returns: a literature survey, available on the Dimensional Fund Advisors website at the following URL: http://www.dfaus.com/library/articles/explaining_stock returns/

3. Fama, Eugene F., and Kenneth R. French,, The cross-section of expected stock returns, Journal of Finance 47, pp. 427-465, 1992.

4. Fama, Eugene F., and Kenneth R. French, Common risk factors in the returns on stocks and bonds, Journal of Financial Economics 33, pp. 3-56, 1993.

5. $\quad$ Fama, Eugene F. and French, Kenneth R., "Dissecting Anomalies" (June 2007). CRSP Working Paper No. 610 Available at SSRN: http://ssrn.com/abstract $=911960$.

6. Greenblatt, Joel, The Little Book that Beats the Market, John Wiley \& Sons, Inc., Hoboken, New Jersey, 2006.

7. Haugen, Robert A., The New Finance: The Case Against Efficient Markets, Prentice Hall, Inc., Englewood Cliffs, New Jersey, 1995.

8. Haugen, Robert A., and Nardin L. Baker, Commonality in the determinants of expected stock returns, Journal of Financial Economics 41, pp. 401-439, 1996.

9. Haugen, Robert A., Comparative Analysis of Two-factor and Multi-factor Ranking Methodologies, accessed on and before January $20^{\text {th }}, 2008$ at the following URL: http://www.quantitativeinvestment.com/GreenblattStudy.aspx

10. Jegadeesh, Narasimhan, and Sheridan Titman, Returns to buying winners and selling losers: Implications for stock market efficiency, Journal of Finance 48, pp. 65-91, 1993.

11. Statman, M., The diversification puzzle, Financial Analysts Journal, 60, 4, July/August, pp. 4-53, 2004.

12. Morningstar Premium Fund Screener, accessed on February $3^{\text {rd }}, 2008$ : http://screen.morningstar.com/AdvFunds/Selector.html 
NOTES 